Pinisi Business Administration Review

Vol. 3, No. 1, March 2021, Pages 1-8

ISSN (Print): 2656-6524

ISSN (Online) : 2775-7102

Homedage: httb://ois.unm.ac.id/index.phb/vbar/index

\title{
Kantian Ethics Towards A Justifiable Business And Trade Practices: Envisaging A Humanitarian Society
}

\author{
Chris O. Abakare \\ Department of Philosophy, \\ Nnamdi Azikiwe University, Ifite Road, 420110, \\ Awka, Anambra State, NIGERIA. \\ chrisabakare@gmail.com
}

(Received: 28 Oktober 2020; Revised: 14 January 2021; Published: 28 March 2021)

\begin{abstract}
The Kantian code of ethics is guided by pure practical reason and since reason is consistent and permits no exceptions to favor the lawmaker or its adherent, the moral law is also consistent and inflexible. This nature of the law is very significant for trade as trade norms cannot be flexed to favor a particular nation or company. This paper believes that Kantian cosmopolitanism should be the credo of business and trade. The reason for this assertion is because the ultimate goal of humanity is a prosperous living of all people in a spirit of unity. Humanity is at its best when rising above the barriers of race, caste and creed. And Kant's ethics has always recommended a path for humanity that leads to this cohesion. Ethical commonwealth, cosmopolitanism, League of Nations and Kingdom of ends have in themselves this onepoint agenda to envisage a humanitarian society that takes pride in peaceable solidarity of human existence.
\end{abstract}

Keywords: Kantian ethics, Business and Trade Practices, Humanitarian World, Godwill.

Copyright (C) 2021 Universitas Negeri Makassar. This is an open access article under the CC BY license (http://creativecommons.org/licenses/by/4.0/)

\section{INTRODUCTION}

A healthy moral standard is essential for humanity to strive for perfection. The moral standard of an institution will determine its value system and influence its priorities. Any institution with an authentic moral system will transmit a healthy culture of values promoting human welfare and transformation. Such a healthy system of morals is humanitarian and holds humanity in communion. This is the sort of moral system which needs to be maintained in every stratum of human living. In trade and business, we are unfortunate to witness a series of unethical practices which undermine the spirit of humanity. The genuine moral standards are often sidelined as they do not support the business practices that injure ethical individuals. 
Today, we need to have a business practice which would uphold the conventional ethical norms while deriving newer applications for the current issues in business. These applications are warmly sought in the world of business today. "Whether products are healthful or harmful, work conditions safe or dangerous, personnel procedures biased or fair, privacy respected or invaded are also matters that seriously affect human well-being" (Shaw \& Barry 2015, p. 5). Thus the humanity is at risk from the misplaced values of the business practice today. In the theoretical ethical philosophy of Kant, we have a model for a viable alternative for human-friendly business ethics. In this work, we explore a few trends of humanitarian ethics of Kant which is an exigency for the world and precisely, for a healthy trade and business.

\section{Social Responsibility Of Business Corporations: A Kantian Standpoint}

Social Responsibility as a term implies in the context of a business that companies and corporations have to contribute towards the social welfare of the society. Sharan defines it as the, "behavior of the organization, which should also be ethical and balance its commitments to investors, workers, customers and the secretaries in general. This means that shareholders should be given a fair and regular dividend and consumers should be asked to pay a fair price. This is because the socially responsible behavior of a company benefits everyone related to it in the long run" (Bright 2021, p. 158). They need to channelize the resources towards the development of society as a whole. The companies involve in acts of social responsibility in order to generate interest and support for their services and products. The companies are sustained by the profit made from consumers and they, in turn, need to support in building communities as responsible corporate citizen. There are multiple ways in which corporations can be socially responsible. A large company may spend portion of its profit for enhancing life of people in its vicinity. It may cater to their ecological needs or provide solar lighting to the streets so that the employees can get back to their homes after their late-night shifts safely. The small firms also contribute to social responsibility in their own way. They would at least be considerate to the society by recycling their own waste and other similar ways. One of the key contributions of Kant's ethics is its presentation of social responsibility evolving from the moral law towards oneself and others. In his duties towards others, Kant designs the social responsibility of every person as a progress towards a moral world. It is in the act of each one fulfilling one's duties in a spirit of reverence for the law we can sufficiently bring to fruition the social responsibility.

Kant's universal maxim theory is essentially meant to promote the social wellbeing of all (Sasa 2019). His duty of kindness and benevolence is a typical case where Kant emphasises the duty as not being content with one's success rather to go out of one's way and reach out to others (Willis 2007). Kant informs that the social responsibility is a call to seek the happiness of others as well. Kantian concept of social responsibility argues that it is a duty to promote the general happiness of all. The mere 
Crish. O. Abakare; Kantian Ethics Towards... $\mid 11$

promotion of general happiness alone does not make a man moral, rather the maxim of one's action should be viable to be universalized leading to the harmony of purposes of the entire human society. The moral person is not to be moved by emotions and inclinations, though they may be genuine. Kant writes:

To be beneficent where one can is a duty, but besides there are many souls so sympathetically attuned that, without any other motive of vanity or self-interest they find an inner satisfaction in spreading joy around them and can take delight in the satisfaction of others so far as it is their own work. But I assert that in such a case an action of this kind, however it may confirm with duty and however amiable it may be, has nevertheless no true moral worth (Star 2019, p. 654).

The Kantian argument is that however noble an action may be it should be done out of duty and purely for the sake of duty. This Kantian hypothesis is the corner stone of any viable business policy which is objective and humanitarian. A genuine business unit holds the credibility of the society and such credibility is guaranteed by this Kantian moral theory. A mere following of the professional and ethical code does not ensure that the business functions in a socially responsible mode. Kantian ethics calls for a genuine understanding of the different ethical facets of business which in its practical sphere is dominated by passions, temptations and emotions. This grasp of the daily course of business activities will facilitate an individual to apply the rational principle and work out a plan of action for a rational integration of passions and emotions. This means a relentless application of reason alone enhances the society in its strive for dutiful action. This application of reason in its practical sphere would inspire the human beings to act purely from duty and would remain as the underlying principle of all business policies. Therefore, when a business firm decides against overpricing a product, it is not to feel happy or to satisfy others, rather it is the firm's duty to do so. They cannot claim any merit for such an action, but bow in reverence to the sublime principle of duty. In Kant's view therefore, duty alone guarantees and upholds business policies which would assure true and fair trade.

The socially responsible act either directly or indirectly contributes to business objective. It is not unfair to expect some benefit from such acts for the corporation as they involve the finance of the company. It is not against Kantian ethics to expect benefits for the company from an act which is performed in a spirit of corporate social responsibility. Business cannot be sacrificed for other ends even if they target social wellbeing. The business has a duty to itself as much a duty to the society. It is acceptable to pursue social responsibilities and yet expect certain benefits from it for the business. A dutiful behavior in business demands a responsible use of business resources and using them purely for non-business purposes may not be in a true spirit of duty. From a business point of view, it may not be considered an offence, for instance when a business unit which spends a huge amount of money for building a bridge in a city for a smooth traffic congestion may permanently install advertisements of the business or use its brand of products for the construction, which may indirectly cut the 
expenses on publicity and increase demand for their products. Businesses channelizing their funds for unauthorized and purely non-business acts could be treated as stealing. The assets which belong to the owners of business cannot be given away for other purposes without a due process. The businesses have a perfect duty to have safety of their assets. Though for Kant being beneficent to the other is a duty (Fryer 2014, p. 54), "to preserve one's life is (also) a duty" (Fryer 2014, p. 55). It is for this reason that from a Kantian position, it is not wrong for businesses to seek self-benefits even in the performance of corporate social responsibilities.

It is beyond doubt that every business runs in view of attaining certain gains and primarily considering profit as one of its key factors. Profit is therefore the end of every business for the survival of every business depends on it. From a deontological viewpoint, it could be argued that profit is a worthy end because it is easily reconcilable with the human person who is also an end. Though this interpretation of Kant's theory of ends may be disputed by some, however, the above claim is interesting from the fact that it is various intermediary ends which lead to an ultimate end. And the human person who is the ultimate end will attend to several other ends in his life and profit is one of such worthy ends which enhance the idea of human person as end. This position may not be acceptable to everyone as some would still argue that in a business firm's striving for profit, the persons involved in business are made victims. Though it could be argued that in ones pursuit for profit the stakeholders would easily be treated as means, what needs to be noted is, whether we are right to call the laborers within the production process and the consumers in consumption process as being used as means. I would instead assert that as long as there is no exploitation of the humanity in those involved in these processes the individual's worth is not at stake. A person may be treated as means only when his humanity is compromised for profit. In normal situations a laborer works for certain hours, which varies depending on the specific norms, where he willingly alternates his service for profit. How would you call this as disrespecting one's humanity? With no exploitation and discrimination in terms of caste, creed and color or in any other form at work places, the human beings retain their status as ends though their work brings profit to the business. The entire profit may not reach the workers who toil hard, yet they cannot be considered ill-treated as businesses have to think in view of contingencies. With no manipulation of workers and no foul play in trade and business, there is no threat to one's dignified existence. Hence for Kant, profit is perfectly reconcilable with one's status as end.

For Kant, his theory of ethics includes social responsibility and holds it in high esteem which should be carried out in a spirit of duty. In his lecture notes we read, "Ethics deals with all obligations, whether they be of charity, generosity and goodness, or of indebtedness, and considers them all together, only insofar as the motivating ground is internal" (Schneewind 1998, p. 76). Thus every business should treat social responsibility as its priority and it is an obligation. 
Crish. O. Abakare; Kantian Ethics Towards... 13

\section{Kantian Code Of Ethics For Business And Trade}

The solidity of the Kantian code of ethics lies in its inflexible nature. Rigidity and stiffness are often considered by many as drawbacks in any system, but its reverse is true in Kant's ethics. Though criticised for being rigid, the strength of Kantian morality lies in its ability to be firm, offering no loopholes for lawbreakers to get away scot-free. For instance, the traffic rule states that do stop when red falls. The illumination of the red light prohibits any traffic from proceeding. The beauty of the traffic rule is that, it is precise with no room for twist and turn. Let us consider what if the traffic law were to state: when red falls you need to stop, however, if there is no vehicle speeding from the other direction, you may proceed in spite of the red signal. In such a case, it offers flexibility but the impact of such flexibility would be catastrophic. Such laws would encourage people to jump signal which would make the law itself meaningless in the long run. Thus inflexibility is the strength of Kantian ethics which is determined by the will unrestrained by inconsistent inclinations. In the Second Critique we read: "The moral disposition is necessarily connected with consciousness of the determination of the will directly by the law" (Kant 1873, p. 138). Again he states; "freedom, and the consciousness of freedom as an ability to follow the moral law with an unyielding disposition, is independence from the inclinations, at least as motives determining our desire..." (Shaw 2012, p. 51). Kant is categorical on the inflexible character of ethics when he states, “... and when morality is in question, reason must not play the part of mere guardian to inclination but, disregarding it altogether, must attend solely to its own interest as pure practical reason" (Kant 1873, p. 141). This is the distinct description of Kantian inflexibility of the moral law where reason alone is its custodian.

Today we witness intense trade wars in business where mutual competition is the order of the day. Thompson defines these trade wars as follows: "Trade war describes the series of tit for tat actions by two or more nations to adjust tariffs, quotas, subsidies, and any number of other economic levers available to governments in the attempt to secure advantages in international trade. That such actions are possible presupposes functioning bilateral or multilateral institutions and procedures for international exchange, as well as some admittedly controversial concepts of fairness for such transactions" (Thompson 1992, p. 29). These situations demand that there is a need for a code of fairness for these trade transactions which can be uniformly applicable to every nation and government. Therefore the Kantian ethics with its inflexible nature offers a genuine internal moral law based on which the trade practices could be worked out. It does not push the weaker nations in a disadvantageous position when it comes to bargain at international trade. The bilateral trade agreements can be signed on humanitarian grounds if the Kantian code of ethics serves as the medium.

It is here that we experience the indiscriminate nature of Kantian ethics that culminates in the inflexible principle of duty. Trade wars do not rise when there is no discrimination of sorts. Kantian code of ethics fosters better worker enhancement and 
they would be neither forced to work nor discriminated. The employees may be even permitted to organize themselves into unions which may be a form of moral community to assert their claims. The Kantian code upholds the liberty of the workers who wish to form associations to sustain their humanity without being used as means by the exploitive firms. Therefore it is morally illegitimate to forbid the employees from collective organizing. They need fair treatment based on their performance and they have a right to claim it either individually or collectively. For Kant, any moral code even if it is only an assertoric hypothetical imperative which is a counsel of skill and the process of attaining our end though not perfect moral end, needs reason as its base (Lipscomb \& Krueger 2010). Thus reason plays an important role in every decision making though at times conditioned by immature human approach. The manager's deliberation may at times impede the rationality of the ethical code proposed by the workers or other stakeholders. If the manager and the administrative body of a firm do not value sound reasoning in their deliberation it would be tough to identify and carry out a moral action. The firm while working on a code has to assure that it is rationally founded and worthily be recognized as an imperative of moral perfection. Though assertoric practical codes are not absolutely faulty, but they cannot command with full authority of reason.

The Decision making body of the firms have to steadily move from the initial counsels of skill towards the absolute commanding power of reason. Such a code would offer impetus for everyone to strive for the performance of moral action. Though this ethical code depends on maxims for its validity, Kant argues that it does not depend on the degree of ones faithfulness to the maxim rather it depends on the specific quality of the maxim one choses to adopt (White 2020). In Religion within the Bare Bounds of Reason, he once again reiterates this view in the form of a question: "But if the human being is corrupted at the basis of his maxims, how is it possible for him to achieve this revolution through his own powers and to become on his own a good human being?" (Palmquist 2015, p. 48). It would mean that a virtuous manager may work strenuously for a genuine ethical code to be in place in his workplace but if he concentrates merely on the grade of commitment to a maxim, then it may not bring forth desired result. It is important to act on quality-maxims for quality moral code. Focusing on faithfulness to any maxim may give us an experience of assertoric imperative as the grade of knowledge is limited while a maxim of sublime quality would lead to categorical imperative which is the ideal of pure reason in its practical sphere. Therefore an ethical code is feasible for business only when it flows from a quality-maxim.

For instance, transmission of technology is fundamental to the escalation of productivity in the world. But a nation or a firm is absolutely free to share its technology with other nations or firms. They can set an ethical code that benefit them and a nation might prefer to export its produce than share technology. A firm is legally permitted to export its produce rather than technology and a maxim evolving from it is permissible but its worth is limited as it has not transcended the hypothetical nature of 
the maxim. A maxim which rises above its hypothetical nature would look forward to cater to the needs of the entire society in a non-consequential manner leading to categorical imperative. Thus a true Kantian code of ethics would command every firm to share technology for common good of the world rising above firm's business itineraries. The categorical imperative with its guidelines for action would form the basis for the ethics of any business organisation. The third formulation of the categorical imperative which brings everyone under the banner of the Kingdom of ends gives the glimpse of the organizational design of the business firm. Just as the moral law invites one to act on a maxim, which can function as a universal law for the entire humanity, the firm should take into account the interests of all the stakeholders in their decision. The business organization should seek the opinion of all those who are going to be affected by the decision, in the process of decision making, that they would not be merely the subjects of the law but also its legislators as the Kantian imperative envisions. Thus, Kantian imperative calls for a consultation of cordiality of all concerned before implementing the policies for the business organisation. In short, for whatever reason, the business organisation should not bypass the various formulations of the categorical imperative, particularly the second formulation which is the categorical imperative in action. As the categorical imperative embraces everyone into its kingdom of ends through the process of universalization, the business unit has a duty to take everyone into account such as producers, shareholders, sales men and consumers. Shaw and Barry write: Respect for the inherent worth and dignity of human beings is much needed today in business, where encroaching technology and computerization tend to dehumanize people under the guise of efficiency. Kant's theory puts the emphasis of organisational decision making where it belongs: on individuals. Organisations, after all, involve human beings working in concert to provide goods and services for other human beings. The primacy Kant gives in individual reflects this essential function of business.

\section{Purity Of Motive Of Business Corporations For A Humanitarian World: Good Will}

Business belongs to the public sphere and therefore should abide by the etiquette required for such affairs. It is not acceptance of the norms of business or contract and money that shapes business, rather mutual trust and fairness. Regarding the fairness in business Shaw and Barry write that, "the notion of fairness in exchanges is more central to business than to any other practice - whether in terms of work and salary, price and product, or public services and subsidies. Without fairness as the central expectation, there are few people who would enter into the market at all. Without the recognition of fair play, the phrase free enterprise would be something of a joke" (Shaw \& Barry 2015, p. 41). The fairness in business is important, as it involves various individuals who are associated with it at different stages, as proprietors, shareholders, managers, sales 
executives and customers. Being fair to all these people is not a matter of civic sense or protocol rather they are the prerequisites which make business genuine. Quality control, safety of the products, trademark monopoly and up-keeping of business contract are inevitable for the smooth functioning of business. The business men can create an artificial scarcity of goods by holding excessive stock which would increase the price of commodities and it would invariably increase the profit. This and other similar acts are clearly against the purity of motive in business. This calls for a solid ethical foundation which evolves from the interior self of an individual to curb these fraudulent practices. And in this search for a viable process the Kantian ethics edges out most other theories.

Kant with his concept of Good will brings an exciting ethical principle into action. In the Groundwork, Kant asserts; "It is impossible to think of anything at all in the world, or indeed even beyond it, that could be considered good without limitation except a good will... unless a good will is present which corrects the influence of these on the mind and, in so doing, also corrects the whole principle of action and brings it into conformity with universal ends" (Healy 2011, 393). Again in the same work, Kant proceeds to assert that good will is good not for what it accomplishes or that it is capable of attaining a specific end rather even if it lacks the capacity to perform an action for whatever reasons, "like a jewel, it would still shine by itself, as something that has its full worth in itself" (Bouville 2008, p. 579). Thus for Kant, good will is a moral vocation which everyone in his lifespan is called to realize and live irrespective of what one's life choices are. It also applies if one opts to build a career as a business executive or a manager. It also has a deep meaning to a trader whether retailer or wholesaler or anyone associated with it. He articulates in a soothing manner:

"Repeated arousing of this feeling of the sublimity of one's moral vocation is to be extolled preeminently; for it acts in direct opposition to the innate propensity to pervert the incentives in the maxims of our power of choice, in order to restore, in the unconditional respect for the law as the highest condition of all maxims to be adopted, the original moral order among the incentives, and thereby to restore, in its purity, the predisposition in the human heart to the good" (Kant 2009, p. 57).

Thus goodwill being the most fundamental to Kant's moral theory, a corporation must necessarily consider it as an obligation to heed and respond. It must encourage its workers for engaging in actions in response to this vocation and develop a respect for themselves as persons who act out of their good will and articulate and formulate their conceptions of good in accordance to it. Goodwill is thus essential in public domain and the corporations need to act out of it as they deal with human beings possessing goodwill. It also is a way of corporation respecting the humanity of the rational agents whose support is essential for them.

However, history is a witness to multiplicity of cases where the goodwill principle has been subdued by unethical forces of the corporations thereby ignoring the goodwill present in those associated with it. The corporate world was taken by surprise when BBC news in 2003 reported the cases involving Enron and WorldCom (Clarke 
Crish. O. Abakare; Kantian Ethics Towards... $\mid 17$

2007). In the Enron case the IRS (Internal Revenue Service) was kept in dark about what was happening and the transactions were too complicated to be understood easily. Enron had countless successful efforts to manipulate its taxes and accounting. The WorldCom scandal on the other hand involved 11billion dollars and the jury found the WorldCom co-founder guilty of seven counts of making false claims besides a count of security fraud (Jackson 2014). The CEOs as highest ranking managers of the organization often present a rosy image about the corporations but often its reverse is true. They even drive us to think that it is naive to trust any of their business claims. The above referred cases are the clear examples where the goodwill has been subdued by the forces of evil. These corporations may have adopted these unethical methods for certain reasons or forced into these actions by certain unforeseen circumstances but they have done it at the expense of the presence of goodwill in them. They have lost the trust of a large number of people who look up to them for responsible behaviour. The purity of motive principle which flows from the rational agent's goodwill has been conveniently bypassed by these above mentioned companies.

These managers and others who are responsible for business may possess numerous desirable qualities which are essential for a human person which are also qualities associated with goodwill. Even if one is gifted with all natural qualities such as kindness, moderation, courage etc..., which are significant to achieve noble goals but if they do not possess goodwill, one cannot be considered morally worthy person. Johnson writes;

Since those are the very qualities of character and temperament that allow one to achieve these noble goals, it is even conceivable that someone might have all of these desirable qualities and achieve all of the noble goals a good will would have, yet still lack a good will and hence still fail to be a morally good person" (Johnson, Good Will and the Moral Worth of Acting from Duty (Hill 2009, p. 21).

And goodwill works through the channel of duty since duty is the sole motivating factor. Goodwill is inherently present in duty and only in a spirit of duty that goodwill is manifested. Kant writes, "we shall set before ourselves the concept of duty, which contains that of a good will though under certain subjective limitations and hindrances" (Shafer-Landau \& Shafer-Landau 2019, p. 72). The goodwill in us may not always choose good and duty can be the motivating principle of moral action. The stakeholders of business may have good intentions and wonderful human qualities and a goodwill to perform in a spirit of humanness but if they don't perform the actions in reverence to duty, inclinations would dominate the good desires. A manger is called to act in goodwill but the motivating factor is duty and not feelings of sympathy. Sympathetic sentiments may induce a top business manager whether a CEO or a division president to define strategies and set organizational goals which are ethically acceptable. But they are not as meritorious as when done out of duty because it is primarily a manager's duty to perform in his capacity as manager. And sympathies and sentiments tamper with the spirit of duty. Sympathetic concern leading to goodwill is 
not to be accepted as a path for dutiful behaviour. Only in acting from duty, a firm becomes anthropocentric guiding humanity towards its moral perfection. The Kantian goodwill principle is a sound ethical principle and at times said to be difficult to apply to business context. The Kantian theories give the impression that they are merely intellectual exercises. The moral maxim may be seen as having been derived from the process of rational faculties. It is not that Kant was unaware of such views for he always associated certain amount of uncertainty with his theories. A theory however vague may be can still be more than handy in crucial decision making situations. The Kant's theory of goodwill inviting to act from duty is perhaps vague but still the best for discipline and order in trade practices.

\section{Social Responsibility And Kantian Path To Profit}

Corporations cannot incur loss and should aim at profit for its survival and fulfill its accountability to the investors. But the corporate citizens are not merely accountable to shareholders but also to a variety of stakeholders from the employees to the ultimate consumers and their responsibility extend to the entire society at large. Therefore the business has to adopt a delicate approach for its sustained existence in this time of competitive businesses and competing firms. The corporations should have a social conscience and exhibit it by providing employment, fair wages, eliminating discrimination and through consumer-friendly programs. The corporations have a responsibility to the nation to refrain from increasing the cost of goods when there is inflation though price increase would be of interest to the corporation. Though from an investors point, it is profit that runs business, the other stakeholders have their rights too. Every stakeholder's right is the collective purpose of business and every one of these agents' needs are legitimate and they ought to be addressed. It is here comes about the need to stretch social responsibility beyond the corporate citizens.

It is often argued that contributing to social responsibility is stealing from investor's kitty and it seems right to state that the assets of business are of the investors. And therefore don't the managers have a duty to manage responsibly keeping abreast with the interest of the investors? I don't think that the argument is too faulty rather a bit too narrow. The investors are not the only people who count in a business. Corporations can exist for purposes beyond simply maximizing profits. And this is the point we intend to address as we proceed from a Kantian deontological ethical approach. Kant's ethics convincingly argues that maximization of social responsibility is the only legitimate path to profit and it does not imply that one would automatically lead to the other or one follows the other. Kant may not have stated it using terms apt for business management and administration in an explicit manner but the issues he touched upon in his long philosophical career amply divulge it. This comes as a surprise to a world-order where social responsibility and profit are viewed as opposing poles with the possibility of only one of them to endure. This position of Kant should be seen in a view of 
Crish. O. Abakare; Kantian Ethics Towards... 19

extension of his deontological trait. Kant does not argue that profit is foreseen or viewed as the effect of social responsibility and the worth of the action depends on its consequences, in which case, it is a consequential approach.

Kant's ethics perceives profit as natural outcome from actions performed out of duty. When a corporation functions on principle of duty in respect for humanity everyone's needs are taken care. When everyone acts on the moral maxim which categorically commands there is no exploitation rather everyone is mutually cared for. Thus there is no dependency of profit on common welfare or common good invariably leads to profit rather when customers and corporate citizens act on the moral maxim which may become a universal norm for everyone then there is both common good and profit resulting from the dutiful behavior of all. Kant out rightly denounces corporate philanthropy where a corporation involves in societal acts by way of charity in order to enhance business fortunes. Here the welfare of the society is a mere consequence of the manipulative tactics of a business firm. Again the corporate philanthropy has only a discounted value as it is used as medium for profit or business expansion. Businesses at times contribute for peace in the nation or volunteer to negotiate with other firms for cheaper supply of goods for a nation which may not be done with best interest for the nation. For Example, a company producing a popular brand of cars may negotiate with a foreign fuel agency on behalf of a nation for its own investment and business success. Huge charitable funds are often given by established business firms to reap benefits for the business. This brings to our frame a discussion on one of business' most popular concepts i:e CSR.

CSR is an important aspect of every business concern as much as profit is and from a Kantian perspective it is immoral to use CSR for the attainment of corporate objectives (Du, Bhattacharya, \& Sen, 2010). And for Kant what counts is whether our actions correspond with the universal moral law which is morally binding and it should be predicated on reason. The Second Critique acknowledges it in the following words: "A practical rule is always a product of reason because it prescribes action as a means to an effect, which is its purpose" (Du, Bhattacharya, \& Sen, 2010, p. 20). Therefore CSR should be carried out of practical reason for the sake of duty and not for profit though it is possible that CSR transmits a healthy opinion to the public and they extend overwhelming support leading to profit. In such case profit is not intended and CSR is not used as means for profit. And profit is maximized as people act on principles of reason for the sake of duty as they acknowledge and reciprocate the service of these dutiful firms.

Though this Kantian view is not completely absorbed by MNCs and trade establishments, there is a growing awareness about it in certain companies. For instance, In July 2007, the Global Compact Leaders' Summit in Geneva which had the representation of over 1,000 business leaders, politicians and civil society representatives, deliberated for a renewed focus on corporate citizenship around the world (Williams 2008, p. 231-32). However a serious breakthrough in tune with this is 
possible only if everyone considers it a duty and act on principles of reason rather than inclinations of personal gains. Kant's CSR doctrine states: "For if none might appropriate more of this world's goods than his neighbor, there would be no rich folk, but also no poor. Thus even acts of kindness are acts of duty and indebtedness, arising from the rights of others" (Altman 2011, p. 79). This is a simple theory pertaining to how CSR needs to work though Kant may not have said it in this sense. The simple reasoning of Kant is, don't get into an amassing-race with your neighbor rather live by the maxim whereby you keep your wealth at least equivalent to your neighbor. This brings in the idea of personal responsibility where everyone takes a personal affirmative stance on CSR. As corporations are run by persons, owning personal responsibilities can alter the way CSR functions and profit may not be viewed as outcome of CSR. Charity begins at home goes an old adage and I would rephrase it as CSR begins at workplace. I mean to state that CSR may have several common agendas for the betterment of the world such as pro-life issues, environmental projects and enhancing growth rate. But, CSR should address the issues of people who matter immediately to the business i: e its stakeholders. Every employer should be treated in a healthy way and not as means to ends. Every business firm should begin its social responsibilities right at its work place. The factory workers are the means to produce profit for the employer but using them only to get what they want is disrespecting their human worth and it is against the moral law. Providing inhumane working conditions and minimum wages do not lead to profit as the employers would be discontented with the business. It is a duty to promote

\section{Kingdom Of Ends As Kantian Cosmopolitanism: Credo Of Business And Trade}

The richness of Kant's categorical imperative is that it does not merely aim individual moral existence rather it proceeds to bring a communion of all moral rational beings. Therefore he offers a variant of the third formulation that reads; "Act in accordance with the maxims of a member giving universal laws for a merely possible kingdom of ends." (Kant 1999, p. 439). This formulation has a close affinity with Kant's closest approximation to a formulation of the law in the First Critique, where he presents the concept of a moral world: "a corpus mysticum of the rational beings in it, insofar as the free will of each, under moral laws, is in complete systematic unity with itself and with the freedom of every other" (Molloy 2019, p. 34). Thus for Kant the individual who is the author of maxim moves on to establish a collective kingdom of ends.

Kingdom of ends is derived from the categorical imperative with rational beings as constituents performing moral responsibilities in a spirit of universality. The rational agents are the members of the kingdom when they give universal laws and are also subjected to the same. They are sovereign beings as law makers and subjects when they obey these laws. This is the nature of the Kantian kingdom of ends where everyone accepts morality as acting in respect for universal laws. Hence, every member of the 
Crish. O. Abakare; Kantian Ethics Towards... $\mid 21$

kingdom has to be treated as an end in itself. The intuitive idea that gives rise to this formulation is that everyone has a moral obligation to act on principles which are acceptable to a community of rational agents who also have a role in legislation for themselves and others. For Kant, it is the principle of autonomy that gives a place to rational agents in the ideal commonwealth or kingdom of ends which is a community of rational autonomous agents who are the authors of the moral laws (Kant 1999). He holds that humanity or rational nature is the only suitable aspirant to be rightly termed an end in itself (Kant 1999). And such persons possess the capacity to set ends, follow those ends, be autonomous and be a member of the kingdom. Holtman observes that, "Respect is the name Kant gives to the esteem we properly feel for whatever possesses or expresses dignity. Thus we can say that, for Kant, dignity resides in the autonomous will and its dictates and is properly met with respect by every rational agent who encounters it" (Hill 2009, p. 109).

This theoretical framework of Kant's ethics is the root of human society which should determine every human activity. Business and trade are activities which are vital to the society and every nation's wellbeing. They should bring people under a single umbrella in a way the Kingdom of ends envisages. The international businesses should subscribe to the ideals of Kantian kingdom and work for the growth and benefits of the entire world transcending their limited interests. They should rise above mere business benefits to enhance the chance for peace. Kant was a firm believer in this theory that he reminds us in Toward Perpetual Peace that, "It was trade that first brought them into peaceful relations with one another and thereby into relationships based on mutual consent, community, and peaceful interactions even with remote peoples" (Bright 2021, p. 195). Though sustainable economic development for the trading agents has to be retained but the communion of all rational beings in an ideal kingdom of ends should be the ultimate goal of business.

Trade and business activities have to eventually lead people to their ultimate earthly purpose which Kant terms as cosmopolitanism. Kingdom of ends is where the cosmopolitan culture is brought to light. When people take responsibility upon themselves acting on universal maxims they transcend their differences to perceive a unity of purpose in the world. Trade and businesses would be carried out in a way that one does not become means for the other. Fair pricing and quality of products should be assured in a spirit of cosmopolitanism. This brings in the principle of cosmopolitan justice in trade and business since justice is integral to trade and business. Kant believed that global justice results from global commerce and fair international trade is possible only in a global set-up where justice is already established. Global fair trade thus presumes global justice. It is not justice in the sale and purchase of commodities within state or between states rather cosmopolitan justice is a justice at a global scale. Kant's cosmopolitan justice envisages constructing an economic order which can meet the demands of justice globally. Boyle argues that this cosmopolitanism would also benefit the trade-world for he states that, "Liberal economic theory holds that these 
cosmopolitan ties derive from a cooperative international division of labor and free trade according to comparative advantage" (Kleingeld et al., 2006, p.64)

Thus cosmopolitanism does not only bring people together rather it also benefits trade itself so that different nations can market commodities on which they have advantage over others. This supports nations and individuals to produce goods at relatively low cost and exchange for goods of other nations. This helps tremendously the potential trading partners who can adopt to a policy of mutual exchange. Besides, people and nations are brought together and trade becomes a way and a tool for the humanity to come together as members of the kingdom of ends or the ethical commonwealth. Kant affirms trade as a way for world-communion when he asserts, "Uninhabitable parts of the earth's surface, seas and deserts, divide this community, but in such a way that ships and camels (ships of the desert) make it possible to approach one another over these regions belonging to no one and to make use of the right to the earth's surface, which belongs to the human race in common, for possible commerce" (Kant 1999, p. 358). Kant sees here a practical difficulty where the people of the world are disjointed by seas and deserts but there are possibilities for trade and commerce to bring the human race together. Kant places tremendous trust in the powers of trade and business for cosmopolitan existence of human race. The barriers of the likes of seas and deserts will be overpowered by the force of trade and commerce.

Again, it is not just natural barriers like seas and deserts will be overpowered by trade and commerce rather even man-made disasters like war will be trounced as well. Kant argues that the spirit of commerce will triumph over the forces of war because war and trade cannot coexist. In Towards Perpetual Peace we read:

It is the spirit of commerce, which cannot coexist with war and which sooner or later takes hold of every nation. In other words, since the power of money may well be the most reliable of all the powers (means) subordinate to that of a state, states find themselves compelled (admittedly not through incentives of morality) to promote honorable peace and, whenever war threatens to break out anywhere in the world, to prevent it by mediation, just as if they were in a permanent league for this purpose; for, by the nature of things, great alliances for war can only rarely be formed and even more rarely succeed. In this way nature guarantees perpetual peace through the mechanism of human inclinations itself, with an assurance that is admittedly not adequate for predicting its future (theoretically) but that is still enough for practical purposes and makes it a duty to work toward this (not merely chimerical) end (Kant 1999, p. 368).

Thus, Kant strikes the right chord with this assertion that commerce will force nations towards a peaceable co-existence. Nations cannot live in enmity for long, as history has shown and of late we have the episode of India sanctioning FDI from Pakistan, who have fought hideous wars not very long ago and between whom bitter animosity has ruled since partition to this day. Thus we see that Kant is being vindicated today and it needs to go on to establish Kantian cosmopolitanism where the rational agents treat each other as ends in the kingdom. This union of all ends in 
Crish. O. Abakare; Kantian Ethics Towards... 23

themselves in the nature of social contract is also an end that is unconditional and the primary duty of all people. These people mutually affect one another as ends of a civil society constituting the ethical commonwealth. This relation of all ends in the structure of a society is the supreme formal condition of all human beings who are secured public coercive laws (Bowie 2002). In this coexistence of persons, the principle for the constitution of commonwealth is that no one drives the other to happiness rather each seek his or her happiness without infringing the freedom of the other (Bowie 2002).

For Kant, it is the experience of history that the human race as a whole cannot but exist peacefully yet cannot avoid occasional conflicts with each other. And they are destined to organize themselves into a cosmopolitan society with laws of their own making. Though there are forces which time to time threaten the very fabric of this cosmopolitan vision but they do make advances toward a federation. Kant calls it as the "vocation of the human race" to march towards such a coalition (Kant 1995). This common vocation, "by which all are united through their common interest in being in a rightful condition, a state is called a commonwealth (res publica latius sic dicta)" (Kant 1995, 445). This cosmopolitan commonwealth may not immediately evolve under single head "but is still a rightful condition of federation in accordance with a commonly agreed upon right of nations" (Holland 2017, p. 140). This also offers sovereignty to every independent nation for "No state shall forcibly interfere in the constitution and government of another state"' (Patrone et al., 2014, p. 54). Thus Kant envisages a unified world that takes pride in a league of all nations. In this quest for unity and oneness, Kant rightly acknowledges the role played by trade and commerce as the promoters of such a league. He expresses that, "It is the spirit of trade, which cannot coexist with war, which will, sooner or later, take hold of every people" (Patrone et al., 2014, p. 55). Thus the Kantian conclusion is a commitment to a world government in which commerce will have a definite role to play. Though critics might call moral cosmopolitanism as unworkable and seek institutional instantiation instead for the safety of human rights, Kant trusts the force of moral law. His emphasis on voluntary goodness reveals his matured thought pattern whereby he respects the humanity in every person. Though stringent laws and stiff penalties may be an alternative, they may not provide human race the moral freedom to evolve into a peace loving community.

It should also be noted that Kant did hint at punishments and laws but his passion for humanity in every person has always favored a kingdom of ends where no one is treated as means (Korsgaard 1992). His categorical imperative often referred as the golden rule is what should guide every human action, trade and commerce included. Maxwell writes: "One of the wonderful things about the golden rule is that it makes the intangible tangible. You don't need to know the law. You don't need to explore the nuances of philosophy. You simply imagine yourself in the place of another person. Even a small child can get a handle on that. There are no complicated rules and no loopholes" (Maxwell 2007, p. 27). 


\section{CONCLUSION}

This paper believes that Kantian cosmopolitanism should be the credo of business and trade. The ultimate goal of humanity is prosperous living of all people in a spirit of unity. Humanity is at its best when rising above the barriers of race, caste and creed. And Kant's ethics has always recommended a path for humanity that leads to this cohesion. Ethical commonwealth, cosmopolitanism, League of Nations and Kingdom of ends have in themselves this one point agenda to envisage a humanitarian society that takes pride in peaceable solidarity of human existence. Trade and business being a significant human activity should lead people towards this coexistence. Our attempt to apply Kant's ethics to business and trade clearly reveals that they have the potency to bring a unity of humanity though often egoistic tendencies overrun this noble cause.

\section{REFERENCES}

Altman, M. C. (2011). Kant and applied ethics: The uses and limits of Kant's practical philosophy. John Wiley \& Sons.

Bouville, M. (2008). Whistle-blowing and morality. Journal of business ethics, 81(3), $579-585$.

Bowie, N. E. (2002). A Kantian approach to business ethics. Ethical issues in business: A philosophical approach, 61-71.

Bright, H. (2021). Precepts of Fair Trade - Kantian Parameters for Business Ethics. (n.p.): Evincepub publishing.

Clarke, T. (2007). International corporate governance: A comparative approach. Routledge.

Du, S., Bhattacharya, C. B., \& Sen, S. (2010). Maximizing business returns to corporate social responsibility (CSR): The role of CSR communication. International journal of management reviews, 12(1), 8-19.

Fryer, M. (2014). Ethics theory and business practice. Sage.

Healy, J. M. (2011). Endangered Minds: Why Children Dont Think And What We Can Do About I. Simon and Schuster.

Hill Jr, T. E. (Ed.). (2009). The Blackwell guide to Kant's ethics. John Wiley \& Sons.

Holland, B. (2017). The moral person of the state. Cambridge University Press.

Jackson, W. J. (2014). American Tricksters: Thoughts on the Shadow Side of a Culture's Psyche. Wipf and Stock Publishers.

Kant, I. (1873). Kant's Theory of Ethics of Practical Philosophy: comprising 1. Fundamental Principles of the metaphysic of morals. 2. Dialectic and methodology of practical reason. 3. On the Radical Evil in human nature. Translated [from the German] by TK Abbott.

Kant, I. (1873). Theory of ethics. Longmans.

Kant, I. (1999). Practical philosophy. Cambridge University Press.

Kant, I. (2009). Religion within the bounds of bare reason. Hackett Publishing. 
Crish. O. Abakare; Kantian Ethics Towards... $\mid 25$

Kleingeld, P., Waldron, J., Doyle, M. W., \& Wood, A. W. (2006). Toward Perpetual Peace and Other Writings on Politics, Peace, and History. New Haven, Yale University Press.

Korsgaard, C. M. (1992). Creating the kingdom of ends: Reciprocity and responsibility in personal relations. Philosophical perspectives, 6, 305-332.

Lipscomb, B. J. B., \& Krueger, J. (Eds.). (2010). Kant's Moral Metaphysics: God, Freedom, and Immortality. Walter de Gruyter.

Maxwell, J. C. (2007). There's no such thing as" business" ethics: There's only one rule for making decisions. Faithwords.

Molloy, S. (2019). Kant's International Relations: The Political Theology of Perpetual Peace. University of Michigan Press.

Palmquist, S. R. (2015). Comprehensive commentary on Kant's religion within the bounds of bare reason. John Wiley \& Sons.

Patrone, T., Formosa, P., \& Goldman, A. (2014). Politics and Teleology in Kant. University of Wales Press.

Sasa, M. S. (2019). An Appraisal of the Concept of Beauty in Immanuel Kant's Philosophy. GNOSI: An Interdisciplinary Journal of Human Theory and Praxis, 2(2), 87-97.

Schneewind, J. B. (1998). The invention of autonomy: A history of modern moral philosophy. Cambridge University Press.

Shafer-Landau, R., \& Shafer-Landau, R. (2010). The Ethical Life: Fundamental Readings in Ethics and Moral Problems (p. 512). Oxford University Press.

Shaw, C. D. (2012). On exceeding determination and the ideal of reason: Immanuel Kant, William Desmond, and the Noumenological Principle. Cambridge Scholars Publishing.

Shaw, W. H., \& Barry, V. (2015). Moral issues in business. Cengage Learning.

Star, D., \& Crisp, R. (Eds.). (2019). History of Ethics (Vol. 1). John Wiley \& Sons.

Thompson, P. B. (1992). The ethics of aid and trade: US food policy, foreign competition, and the social contract. Cambridge University Press.

White, M. (2020). Kantian ethics and economics. Stanford University Press.

Williams, O. F. (2008). The UN global compact: The challenge and the promise. In Leadership and Business Ethics (pp. 229-249). Springer, Dordrecht.

Willis, J. (2007). Brain-friendly strategies for the inclusion classroom. ASCD. 
26 Pinisi Business Administration Review

Volume 3 Number 1, Marchh 2021. Pages 9-26 